\title{
Oil spills: cases and consequences analysis
}

Oil spills are natural disasters that affect marine life, devastate ecosystems and different social series. They have a high risk of not only damaging the environment and human health, but also damaging the image of companies linked to these events. Thus, this article seeks to compile the main events in Brazil and the rest of the world to categorize their causes, impacts and social implications. And through a critical analysis to understand how such accidents could be avoided or better solved, bringing the most effective cleaning methods today. For this reason, it was clear that in many cases of spills, the actual damage generated is omitted to avoid public retaliation, but this only reinforces the need to disseminate the importance of environmental surveillance in the oil sector and to foster new technologies that seek alternative methods. decontamination of water bodies. In addition to making this subject increasingly present in society's daily lives, so that better working conditions and environmental care can be demanded.

Keywords: Environmental disaster; Water pollution; Biggest oil spills; Mitigation; Cleanup methods; Petroleum.

\section{Derramamentos de óleo: análise de casos e consequências}

\begin{abstract}
Os derramamentos de óleo são desastres naturais que afetam a vida marinha, devastam ecossistemas e diferentes séries sociais. Eles apresentam um alto risco de não só prejudicar o meio ambiente e a saúde humana, mas também a imagem das empresas vinculadas a esses eventos. Assim, este artigo busca compilar os principais acontecimentos no Brasil e no mundo para categorizar suas causas, impactos e implicações sociais. E através de uma análise crítica para entender como tais acidentes poderiam ser evitados ou melhor resolvidos, trazendo os métodos de limpeza mais eficazes da atualidade. Por isso, ficou claro que em muitos casos de derramamentos, os reais danos gerados são omitidos para evitar retaliações públicas, mas isso apenas reforça a necessidade de disseminar a importância da vigilância ambiental no setor de petróleo e de fomentar novas tecnologias que busquem alternativas métodos. descontaminação de corpos d'água. Além de tornar esse assunto cada vez mais presente no cotidiano da sociedade, para que sejam exigidas melhores condições de trabalho e cuidados com o meio ambiente.
\end{abstract}

Palavras-chave: Desastre ambiental; Poluição da água; Maiores derramamentos de óleo; Mitigação; Métodos de limpeza; Petróleo.

Topic: Engenharia de Petróleo e Gás

Reviewed anonymously in the process of blind peer.
Received: 02/01/2021

Approved: 27/01/2021
Maria Leticia Alves Goulart (iD)

Universidade Federal de Pelotas, Brasil

http://lattes.cnpq.br/9743525847874689

http://orcid.org/0000-0002-6050-5866

mlagoulart@hotmail.com

Larissa Loebens (D)

Universidade Federal de Pelotas, Brasil

http://lattes.cnpq.br/2881245126256479

http://orcid.org/0000-0002-4270-4183

laryloebens@hotmail.com

Rômulo Henrique Batista de Farias (10

Universidade Federal de Rio Grande, Brasil

http://lattes.cnpq.br/9851332686858804

http://orcid.org/0000-0001-8299-1538

rfhostos@hotmail.com

\begin{abstract}
Carolina Demarco (iD
Universidade Federal de Pelotas, Brasil

http://lattes.cnpq.br/3166438553797256

http://orcid.org/0000-0002-3826-404X

carol_demarco@hotmail.com

Maurízio Silveira Quadro (ic

Universidade Federal de Pelotas, Brasil

http://lattes.cnpq.br/1749935262841216

http://orcid.org/0000-0001-8236-7479

mausq@hotmail.com
\end{abstract}

\section{Referencing this:}

GOULART, M. L. A.; LOEBENS, L.; FARIAS, R. H. B.; DEMARCO, C. F.; QUADRO, M. S.. Oil spills: cases and consequences analysis. Revista Ibero Americana de Ciências Ambientais, v.12, n.1, p.397-416, 2021. DOI: http://doi.org/10.6008/CBPC2179-6858.2021.001.0033 


\section{INTRODUCTION}

The increased need for fossil fuels has increased marine exploitation and resulted in improved laws and surveillance of water quality and marine ecosystems (ROS et al., 2019). We are actually living in the oil age, petroleum has many uses and untill now there is no alternatives ecologically friendly to replace it (VASSILIOU, 2018; LANGTON et al., 2019). Oil spills remain an inevitable risk in the exploration, production, and transportation of hydrocarbons (GUO et al., 2019; ZHANG et al., 2019). Their impacts on the environment are usually severe, hence effective and efficient response strategies are essential to minimise environmental damage (IFELEBUEGU et al., 2017; CAMUS et al., 2019; Jl et al., 2019).

So far, there are no adequate ways to exploit, use and treat huge quantities of contaminated materials, leading to waste of a potential source of raw materials and many other environmental problems (LASSALLE et al., 2019; LATIF and Iskandar, 2019). Which generates large volumes of waste material in the surrounding environment as waste (HOANG et al., 2017). Different materials and methods for oil spill treatment are used for different types of conditions (DEBS et al., 2019; NAIR et al., 2019; SIMONSEN et al., 2018). For sustainable and effective oil spill treatment, ductile materials should be studied extensively as a material is unlikely to be suitable in all possible oil spill scenarios (DUONG et al., 2018). In addition, local legislation also affects the choice of these pollutant cleaning and treatment features (DOSHI et al., 2018). A number of effective materials can be utilized but the wrong choice can actually increase the amount of hazardous waste, which will require costly disposal (MURALIKRISHNA et al., 2017). And the oil spill cleanup techniques that have been used to control or reduce the immediate effects of an oil spill can help only to some extent and this underscores the need of a more novel technique for oil cleanups (WADHWANI, 2017; CHEN et al., 2019).

The aim of some studies nowadays is to compare how different techniques to remediate petroleum hydrocarbons contaminated by employing soil microcosm studies, and other types of analysis (VARJANI et al., 2019). Soil collected from six locations across Canada were used in a laboratory experiment to assess persistence and toxicity of a medium PHC product to soil invertebrates and in disturbed areas where topsoil was stripped, than no fauna was observed during the processing of field soils. Highlighting the high level of pollution caused by oil in contact with the soil, not just the sea (GAINER, 2019). Tissue samples were collected from animal groups exposed to Norwegian oil in seawater and examined under the microscope and accumulation and toxicity studies of the two synthesized monoaromatic compounds showed morphological abnormalities in such beings, highlighting the dangerousness and spread of the oil in the system of living BEINGS (S $\varnothing$ RENSEN et al., 2019). Also, there are many underlying factors responsible for the effects of crude oil and its induced abiotic stresses on the composition of stressed plants, which are poorly understood and require much study (ODUKOYA et al., 2019; OLARANONT et al., 2018; TAYLOR et al., 2018).

The formation of an oil film after its spill depends on many different factors, such as climate, water surface velocity, water salinity, water evaporation air, biodegradation and water-oil emulsions that drastically affect the change in viscosity, density, interfacial tension force. In addition, some oil spill contents, 
such as aromatic, acids and alcohols cause water pollution for a much longer time (HOANG et al., 2017; JIMÉNEZ, 2018; SØRHEIM et al., 2018; ROLANDSEN, 2018; MULLIN, 2018; HSU et al., 2019; NISSANKA et al., 2019).

Natural gases always contain a certain amount of non-hydrocarbon components. These are nitrogen, carbon oxides, water vapor, elements such as helium, neon, argon, hydrogen sulfide and other sulfur compounds (OVERTON, 2020). Free gases accumulate in the lithosphere or are discharged through areas of high permeability to the earth's surface and escape into the atmosphere. There is also the associated gas, which is not commercially significant but also generates pollution and in the case of oil spills are the first to come into contact with the environment (PIKOVSKIY et al., 2019; SPEIGHT et al., 2019; HAZRA et al., 2019).

Brazilian environmental laws provide stringent sanctions for such environmental pollution and fines that motivate companies to hide certain details related to the damage caused and also to seek more effective and less expensive methods of mitigation (ICLG, 2019). Establishing the strict liability of shipowners to be responsible for costs and damages for a discharge of oil is essential (CROFTON, 2019). There is a lack of many multinational corporations, adoption of an environmental sustainable approach that will avert issues of crude oil pollution and environmental degradation, and reduce human health consequences (KALU et al., 2019). Moreover, in every place in the world there are laws particularly related to the incidents cited, which must be strictly adhered to.

This paper is justified by the growing worldwide environmental concern about disasters involving the oil industry. It is noteworthy that the knowledge of the causes and the history of the companies involved with the theme has great collaboration in understanding and solving the problem. In general, this work aims to better visualize any theory surrounding environmental contamination of oil spills and to investigate the possible effectiveness and repercussion of the treatments currently employed.

\section{METHODOLOGY}

Given the relevance of the issue, a review study was conducted on the main factors that should be considered when oil spills occur, as well as the reading of several real cases and the choice of major international and brazilian spills.

The main sources of research were SPE's OnePetro platform, which concentrates a huge variety of articles related to the oil industry, the ITOPF website that is a specialist in the subject and provides various articles and technical publications about oil spill accidents and the tools used for cleaning them, especially in the Elsevier's papers. Some online sources that reported the accidents that occurred in his time were also used, with preferences for journalistic texts. The keywords used were in Portuguese 'derrame de oleo' and 'derrame de petroleo' and the places of accident years. But since most of the readings were in English, the main words used as a search engine were 'oil spill' and 'clean-up oil spill'. Most of the specifications used are included in the 2017-2020 publications (which will still be available in selected magazines, but are already online).

The choice of case studies represented here was based on the selection of criteria of relevance and 
media dissemination, correlating the actual effects and the extent of the actual damage, since the correspondence between the amount of content dispersed in the medium and the ones that do not always correspond to damage to fauna, flora and in particular to society. Thus, comparisons were made between the way accidents occurred, their possible cleaning methods, what could actually be done at that time, and even some improvements that could be applied.

The most relevant factor is the social impact caused, with sections in this paper that highlight the behavior and social and environmental consequences of the cited disasters, and the critical analysis of the facts is the strong point of discussion of this document.

This work has a long preparation time involved, always looking for relevant data and as there is a lot of information on some topics related to environmental disasters, the most relevant data has been assimilated, summarized and can be edited in tables or subjects to a comparative critical analysis to simplify the understanding and reading of those in contact with this papers.

\section{Major environmental impacts due to oil contamination}

Environmental damage caused by oil spills can be permanent and cannot be compensated in terms of payments of Money (BAGGA et al., 2018). Unfortunately, oil spills contaminate water and restrict the access of marine animals to their habitat and food supplements. And while there are already numerous methods of separating oil and water, none of them are effectively safe enough to make that previously contaminated water safe for all marine and human life (CAO et al., 2019). Mechanisms such as dispersion, dissolution, emulsification, oxidation, aggregation and sedimentation according to him can cause some oil particles to sink into the sea and incorporate into the sediment and clay, being able to quickly penetrate the whole system of the human body and marine life (ZHU et al., 2018; HAO et al., 2019).

In addition, since most cleaning techniques focus on the interface of oil-water contact without further in-depth investigations, with only visible surface parameters, the water will remain polluted and harmful (SUN et al., 2018). It is a fact that besides marine life, the impacts related to human activity on the contaminated area are serious, since ecotourism and fishing are the most affected areas (ZOVEIDAVIANPOOR et al., 2018; SHANG et al., 2019; BAUTISTA et al., 2019). In water the stain generated by discharged hydrocarbons fluctuates by the difference in density, preventing the entry of light and gas exchanges, initiating the solubilization of water soluble compounds and the effect of different populations (BANERJEE et al., 2019). One of the first marine populations affected by an oil spill is plankton, which cannot survive without the possibility of photosynthesis due to the hydrocarbon barrier (LIU et al., 2019; HSU et al., 2019). Macroinvertebrates are also affected, and individual soft-bottom habitats, communities and stocks of marshes, macrofauna, waterfowl and estuarial biotopes need to be assessed and rated for vulnerability, including affecting the planning and classification of oil spill contingencies (FOEKEMA, 2020; GROTE et al., 2018). The last affected population is the population of benthos or des macroinvertebrates that live at the bottom of rivers and mares (GROTE et al., 2018; SCHWING et al., 2020).

The image of companies in environmental scandals such as those cited throughout the work is 
tarnished for a long time after their occurrence, and fine sanctions and criminal prosecutions last for a long time. As is the case of the most famous Brazilian incident in the Guanabara Basin in 2010, which have new cases of compensation in court every year (FRIES et al., 2019).

\section{RESULTS AND DISCUSSION}

\section{General classification and cleaning methods}

In addition to categorizing the type of spill, it is important to identify the most effective cleaning method and practice it quickly. This step is crucial in the extent and severity of the accident, since as soon as the leak is detected the remediation process of the hit site should be started instantly (KLETZ et al., 2019).

Several experts claim that there is no simple procedure to recommend for all spills. Spilled oil behaves differently, depending on the type of oil, the surface it is spilled on, soil and subsoil conditions, and prevailing weather conditions. The cleaning method selected for a given set of circumstances should take into account these variations and the sensitivity of the site as a resource, be it a water resource, an area of special amenity value or wildlife interest (ARDESHIRI et al., 2019). In most cases, a combination of oil containment, recovery and subsequent disposal is involved (BHARDWAJ et al., 2018). This in turn implies some possibly some treatment or recovery process and then disposal. There are several bioremediation tools, such as emulsifiers, multi-enzymatic liquid (MEL), microbes and rice straw that mainly aim at the recovery of the benthic community, being the temporal efficiency in the removal of total petroleum sedimentary hydrocarbons (TPH), reduction of residual toxicity and recovery of bacterial diversity, growth of microalgae and benthic production determinant in the effectiveness of site cleaning (LI et al., 2019).

The cited combination can be seen in a study (LEE et al., 2019) who uses different API and compositions oils with distinct salinities to highlight the need of different types of cleaning, such as the use of emulsifiers, microbes, rice straw, MEL. There are today many other cleaning processes cited in scientific articles, but whose uses have not yet been disclosed by any oil industry company and, therefore, have not been cited ahead (PENG et al., 2018; KOULOUKOUI et al., 2019). But a good potential work is using the capability of products to absorb the oil with cellulose-based adsorbents (LIU et al., 2019).

On the industrial development, petroleum transportation, oil industry, oil-refining processes and maritime accidents forethought of people are considered as the primary reasons causing the abovementioned oil spills and there are several ever-developing techniques to satisfy the strategies of oil spill recovery and removal the fastest, a novel investigation of oil and heavy metal adsorption capacity from asfabricated adsorbent based on agricultural by-product and porous polymer is one of them. Vietnam is one of the top countries in rice exports, thus, rice straw and husk are considered as the extremely cornucopia material sources (HOANG et al., 2018).

The weather and seasons prevailing during the spill period play a decisive role in its magnitude. The high temperatures and wind speeds increase evaporation, which leads to a decrease in the toxicity of oil remaining in water. Temperatures affect the viscosity of the oil as well as the ease with which it can be 
dispersed and with which it can penetrate sediment. There is also seasonality of the species that are in that habitat (TOZ et al., 2018).

Oil spill classifications can be described and listed according to many factors, the Table 1 bellow was wrote based on several authors, it is a resume, that way is easier to identify the degree of gravity of the spill.

Table 1: Oil spill classification developed based on publications addressing subject matter information for choosing the degree of accident risk.

\begin{tabular}{|c|c|c|c|c|c|c|}
\hline \multicolumn{3}{|l|}{ SIZE } & \multicolumn{2}{|c|}{ MATERIAL SPILLED } & \multicolumn{2}{|l|}{ DISPERSION TYPE } \\
\hline Small & Intermediate & Big & Heavy oil & $\begin{array}{ll}\text { Light } & \text { oil/other } \\
\text { derivatives } & \end{array}$ & Instant & Continuous \\
\hline $\begin{array}{l}\text { They can be } \\
\text { easily } \\
\text { remedied, } \\
\text { associated } \\
\text { with small } \\
\text { leaks with } \\
\text { efficient early } \\
\text { detection } \\
\text { systems. } \\
\left(\mathrm{LESS}^{3} \text { THAN }\right. \\
1 \mathrm{~m}^{3} \text { ) }\end{array}$ & $\begin{array}{l}\text { Most spills are } \\
\text { this size. It has } \\
\text { serious and } \\
\text { difficult to clean } \\
\text { consequences } \\
\text { but can be } \\
\text { controlled with } \\
\text { rapid detection. } \\
\text { (UP TO 1000m }{ }^{3} \text { ) }\end{array}$ & $\begin{array}{l}\text { They attract } \\
\text { considerable } \\
\text { attention from } \\
\text { the } \\
\text { people/media. } \\
\text { They are made } \\
\text { up of crude and } \\
\text { difficult to clean, } \\
\text { it is the most } \\
\text { expensive type } \\
\text { to treat. } \\
\text { generally } \\
\text { impossible to } \\
\text { mobilize } \\
\text { sufficient means } \\
\text { to } \\
\text { clean up this } \\
\text { spill. } \\
\text { (THOUSAND M }{ }^{3} \text { ) }\end{array}$ & $\begin{array}{l}\text { They usually } \\
\text { make up the } \\
\text { largest } \\
\text { portion, are } \\
\text { more } \\
\text { difficult to } \\
\text { remove and } \\
\text { cause major } \\
\text { damage to } \\
\text { local marine } \\
\text { life. They } \\
\text { have very } \\
\text { low API } \\
\text { gravity. }\end{array}$ & $\begin{array}{l}\text { They are volatile } \\
\text { fractions or petroleum } \\
\text { derivatives and may } \\
\text { rely on the use of } \\
\text { additives thus } \\
\text { facilitating } \\
\text { decontamination. But } \\
\text { they can also be very } \\
\text { risky as they penetrate } \\
\text { the sediment easier. }\end{array}$ & $\begin{array}{l}\text { Content is } \\
\text { dispensed at once } \\
\text { into the } \\
\text { environment. It is } \\
\text { rare for thousands } \\
\text { of cubic meters of } \\
\text { oil is released } \\
\text { instantaneously is } \\
\text { linked to the } \\
\text { speed of } \\
\text { propagation and } \\
\text { time of contact } \\
\text { with the coast. }\end{array}$ & $\begin{array}{l}\text { For long } \\
\text { periods of time } \\
\text { (large } \\
\text { quantities that } \\
\text { need to be } \\
\text { quantified). } \\
\text { Consider the } \\
\text { accessibility of } \\
\text { the removal } \\
\text { site or those } \\
\text { affected by the } \\
\text { accident. }\end{array}$ \\
\hline
\end{tabular}

For Table 1 above, the references used was Liu et al. (2019), Zafirakou et al. (2018), Vidmar et al. (2018), Wilkinson et al. (2017) and Duke (2016).

\section{Oil Containment}

It is important to know that there are barriers that focus on storing spilled oil and others on only containing contamination from other regions, including burning of all expelled material (RYPKEMA, 2018).

Ocean Barriers are generally manufactured from rugged, UV-resistant polyurethane, polyester, polyvinyl chloride or neoprene-lined fabric, they are large, robust barriers that require a unit of force for launching and retracting air blowers (BUCELLI et al., 2018). For padding and greater skill of the user. However the Oil Burning Barriers are used to contain fire hazardous stains or to concentrate stains for later intentional ignition (SAMUDRE et al., 2019). Current models are constructed with a water-cooled blanket through an auxiliary pump and can be used multiple times as it is resistant to high temperatures and it can move the incendiary spot to more suitable locations (FINGAS, 2018).

According to some bibliographies (MITCHELMORE et al., 2020; EVERS et al., 2019; SHAH et al., 2019; SAMUDRE et al., 2019; JØRGENSEN et al., 2019; WALKER et al., 2018), there are methods that are most widely used and effective in cleaning and treating spilled oils, as shown in the Table 2. 
Table 2: Oil spill classification developed based on publications addressing subject matter information for choosing the method of cleaning or containment.

\begin{tabular}{|c|c|}
\hline METHOD & SE AND CHARACTERISTICS \\
\hline DDispersant Use & $\begin{array}{l}\text { The main purpose of dispersant application is to decompose an oil slick into numerous small drops that rapidly } \\
\text { dilute in the water column and are subsequently degraded by naturally occurring microorganisms. Generally } \\
\text { used attached to floating barriers, oil collecting materials and vessels, absorbent materials. Its use should take } \\
\text { into account oil characteristics, sea and climate conditions, environmental sensitivities and national } \\
\text { regulations. It is a technique that can involve cost, however it is widely used today. }\end{array}$ \\
\hline SSkimmers & $\begin{array}{l}\text { The main technique adopted by many government authorities is the mechanical recovery of oil from the sea } \\
\text { surface. This is usually achieved by using barriers to concentrate spilled oil, allowing the skimmer to selectively } \\
\text { recover and pump oil into storage. Many different types of skimmer exist with designs optimized to handle } \\
\text { different operating ranges, oil types and environmental conditions. They can be divided into oleophilic or non } \\
\text { oleophilic. }\end{array}$ \\
\hline $\begin{array}{l}\text { MMec } \\
\text { Tools }\end{array}$ & $\begin{array}{l}\text { Generally for heavy and thick oils, excavators can be used to recharge spilled oil, as well as the use of other } \\
\text { leveling machines that can be easily used but generally have a lower recovery factor for recovered oil. }\end{array}$ \\
\hline $\begin{array}{l}\text { MManual } \\
\text { collections }\end{array}$ & $\begin{array}{l}\text { Using squeegees, shovels, sacks or buckets. It is a method used when the spill occurs very close to the shore or } \\
\text { beach sand. It allows the selection of spilled material to be carefully separated into some desired categories. It } \\
\text { is necessary to understand the classification of treatment approaches as well as subsequent results of the } \\
\text { possible criteria for the analysis in each scenario. }\end{array}$ \\
\hline SSurf Washing & $\begin{array}{l}\text { Used in sand, gravel, crystals and even charcoal. They are washes with natural actives, based on the water force } \\
\text { against the contaminated surface. Agitation and abrasion remove oil embedded in the sediment, it is a joint } \\
\text { process with manual removal and use of adsorbents. }\end{array}$ \\
\hline Sieved Sands & $\begin{array}{l}\text { Machines pass by collecting contaminated sands and sieves removing oil particles. This process may culminate } \\
\text { in the removal of all sand and disposal or possible return of it to the beach after decontamination. }\end{array}$ \\
\hline BBioremed & $\begin{array}{l}\text { Several processes that culminate in the acceleration of the natural biodegradation of oil in simpler compounds } \\
\text { and absorbable by the dispersed medium. They basically consist of natural oil degrading assets, it is a process } \\
\text { that can be highly controllable and is widely used on land. }\end{array}$ \\
\hline
\end{tabular}

In one article (SUÁREZ et al., 2018) said that the use of mechanical barriers in the process of contention of the oil is essential to ensure the environmental health, even that this is for a short time, and that this process can be divided into four steps that set up a cycle. The first step is the identification of environmental critical elements (the ECEs), the next is the development of performance standards for each of ECEs, the third step is the identification of assurance tasks and acceptance criteria to verify compliance with Performance Standards, and the last one is the taking of corrective actions.

It is noteworthy that these corrective measures need to be assertive in the criterion of decontamination of the environment, and that they require specific techniques, usually expensive and time consuming, to recover the degraded area as much as possible (OSTROM et al., 2019).

\section{Main international spills}

\section{Persian Gulf 1991}

The largest oil spill in the world was not an accident. It was the result of a war. During the 1991 Gulf War, when Iraq forces withdrew from Kuwait, they opened pipelines and oil well valves and defined fire as a measure to prevent US forces from landing in the area (BALMER et al., 2019). The fire started after the first well opened in January 1991 lasted until the last well was closed in april of that year. As a result, some 240 million gallons of oil were released into the Persian Gulf, killing hundreds of fish and marine mammals.

About 67 million tons of oil burned, the removal of oil in the sea occurred first by fencing the spot, then by mechanical separation and oil and sand sieving. In the soil there was thermal desorption. All recovered oil was reused (FOWLER, 1993). The company says the removal of the contaminant was 99 percent effective, but several media outlets that came back a few years later say the statement is far from reality. 
Taken together, the damage to the economy could reach more than 1.6 billion of dollars, according to experts (FAKHRZADEGAN et al., 2019).

\section{Deepwater Horizon 2010}

One of the best-known Gulf of Mexico oil spills and BP oil spill, Deepwater Horizon's oil spill is considered to be the largest oil spill in the history of the oil industry. In April 2010, the accident began after a leaking oil pipe under the sea, leading to the explosion of BP's Deepwater Horizon oil rig in its Macondo Prospect. The accident killed 11 men working off the rig and also resulted in an oil spill that continued for more than three months. It is estimated that 53,000 barrels were flowing in the Gulf of Mexico every day. The accident also caused major damage to the marine environment. According to the Center for Biological Diversity, the oil spill has killed more than 82,000 birds, 25,900 sea mammals, 6,000 sea turtles and tens of thousands of fish, among others.

A month after the start of the leak the company begins a procedure known as top kill, which attempts to pump enough mud into the well to eliminate upward pressure from the oil and clear the way for a cement cap to be placed. The attempt fails. As well as the attempt to place a containment dome on spilled oil, frustrated by the fluctuating action of gaseous hydrates. An auxiliary collection system comprising several devices, also connected to the BOP, was then started, increasing the collection rate to approximately 25,000 barrels of oil per day. The success of these procedures paved the way for a bottom kill, considered the most likely means of permanently sealing the leak. This involved pumping cement through a channel - known as a relief well - which paralleled and eventually crossed the original well (HADER, 2019).

In this same place due to the escape of some particles was introduced a species of bacteria capable of degrading the hydrocarbons. Losses are estimated to this day, just after the crash hit, US President Obama at the time led BP to create a USS 20 million compensation fund for those affected by the spill. Fines on individuals and separate cases were also paid, about USS 7.8 billion. A migratory bird and sea animal reimbursement agreement was stipulated and contained fines of more than USS 4.5 billion, of which USS 1.26 billion would go to a DOJ-supervised discretionary fund, USS 2.4 billion to the National Fisheries and Wildlife Foundation (NFWF) and USS 350 million to the National Academy. In January 2013, Transocean agreed to a USS 1 billion civil fine under the Clean Water Act. Approximately USS 800 million of this amount went to gulf restoration projects, and the rest was paid to the federal government. The company also pleaded guilty to criminal violations of the Clean Water Act, resulting in a USS 400 million criminal fine. And in July 2013, Halliburton agreed to pay a USS 200,000 fine after pleading guilty to criminal allegations that its employees had destroyed evidence related to the leak. He filed claims with the plaintiffs steering committee for about USS 1.1 billion in September 2014. In November 2015, Anadarko was held responsible for about USS 159.5 million in civil fines for its role in the disaster (EPA, 2017).

\section{Ixtoc 1979}

In June 1979, Campeche Bay in the Gulf of Mexico saw the collapse of an oil well operated by the 
Mexican oil company Pemex. About 140 million gallons of oil - nearly 10,000 to 30,000 barrels of oil were being discharged per day - was discharged into the sea over a period of ten months. The oil slick resulted from the accident measured at around 1100 square miles and was surrounded by Rancho Nuevo, a prominent nesting site for Kemp's Ridley sea turtles on the Mexican shores. The Ixtoc platform fire and collapse is eerily similar to what happened at Deepwater Horizon: in both cases, the blowout preventer didn't work.

The initial well flow rate was estimated from the most credible sources as 30,000 barrels/day $(1,260,000$ gallons/day) in the first two months of the disaster. As a measure to reduce the impact on marine life, thousands of sea turtles have been moved to the cleaner part of the ocean. Manual oil removal was used, along with drilling 2 oil pressure relief wells. Then the Coast Guard withdrew when Pemex installed an "sombrero" inverted sink in the well (NELSON et al., 2019).

The company claims that near-surface containment barriers have been very effective and marine life is rapidly recovering. The most profound economic impact was felt by the region's tourism industry, whose expenses on the Texas coast were estimated at USS 445 million. Along with the lawsuits of the United States and Texas governments, several allegations have raised the costs to be paid to nearly USS 400 million. Source indicate that the total minimum spending was USS 800 million (MURAWSKI et al., 2020).

\section{Atlantic Empress 1979}

It was in July 1979 that two tankers were collided in the Caribbean Sea off the coast of Tobago during a tropical storm. When the accident occurred, Atlantic Empress was on its way to Beaumont from Saudi Arabia, while Captain Aegean headed from Aruba to Singapore. Immediately after the accident, the supertankers - the Atlantic Empress and Captain Aegean - began to leak their cargo and catch fire. According to reports, about 88.3 million gallons of crude oil were thrown into the sea, making the accident the world's largest oil spill. In addition, the accident also took the lives of 26 crew members when Atlantic Empress later exploded. The main means of containment was the use of relatively fast, 20-day dispersants (VARSAMI et al., 2018). But what remained at sea will need another 50 years to be mitigated naturally. The cleanup effort cost approximately USS 2.5 billion and the total cost was USS 9.5 billion, including fines and settlements, and is one of the most expensive reprimands ever recorded (ZHANG et al., 2019).

\section{Odyssey 1988}

Odyssey, the Liberian tanker loaded with about 43 million gallons of North Sea crude in its cargo, broke in half and sank off the coast of Canada in November 1988. According to reports, the ship sank 700 miles offshore off the coast of Nova Scotia an explosion aboard. The ship's cargo caught fire as it sank, dumping 43 million gallons of oil into the Atlantic Ocean. The oil spill covered an area of $4.8 \mathrm{~km} \times 16 \mathrm{~km}$, while the amount of oil reached on the coast was minimal. In addition, it is assumed that all 27 crew members aboard the Odyssey died in the incident.

As the current and wind spread oil over a giant area, there were no effective barriers to containment, the main method employed was bioremediation linked to the use of dispersants. This whole strategy cost 
over USS 2 million to employ (KUMARI et al., 2018).

\section{Union Oil Company 1969}

It was an explosion (caused by inadequate safety precautions taken by Unocal, then known as Union Oil) from a 3,500-foot Union Oil well about 5 miles off the coast of Santa Barbara, California. About three million gallons of oil spilled until it could be sealed 11 days later, covering 800 square miles of ocean and 35 miles of coast and killing thousands of birds, fish and other wildlife. The disaster is largely considered to be one of the key impulses of the environmental movement and stricter government regulation, including the signing by President Richard Nixon of the National Environmental Policy Act, the creation of the Environmental Protection Agency in 1970. It also inspired the Senator from Wisconsin. Gaylord Nelson to found the first Earth Day (SPEZIO, 2018).

In containment of the disaster, workers pumped chemical mud through the 3,500-foot well at a rate of 1500 barrels per hour. It was covered by a cement plug, but residual amounts of gas continued to leak and another leak emerged weeks later, releasing oil for months to come. Therefore, skimmers collected oil from the ocean surface. In the air, planes threw detergents into the tar-covered ocean in an attempt to break the stain. On beaches and harbors, the straw was spread in oily patches of water and sand. The straw absorbed the black mess and was then collected. Rocks have been steam washed, cooking marine life like limpets and mussels that bind to coastal rocks. New federal policies established after the disaster required offshore oil rig operators to pay unlimited amounts for oil spill cleanup costs, along with fines of up to USS 35 million. In terms of investments, Exxon Valdez spent about USS 23 billion from 1989 to 2009 on remediation and fines on the spill (FLACKS, 2019).

\section{Most relevant spills occurred in Brazil}

\section{Campos Basin 2011}

US oil company Chevron was responsible for one of the largest and worst oil spills in Brazil. The spill was thousands of liters and occurred in the Campos Basin on November 8, 2011. The incident made Chevron executives defendants and could still result in huge penalties.

Assessment reports indicate that Chevron could have prevented the leak. To get an idea even with the company's emergency plan, the oil slick continued to spread across the ocean. By mid-December the spot was $3.8 \mathrm{~km}$ long and about 1 square kilometers in area. Chevron's head of Brazil's operation, George Buck, said Chevron had underestimated the pressure from subsea oil deposits during drilling, causing oil to rise from the well and leak into the surrounding seabed. Mr. Buck said the spill was connected, but residual oil from the underwater rock continued to flow near the well at the Frade oil project, 370 kilometers off the Brazilian coast. When police searched for methods to clean up the spill, Fabio Scliar, head of the Federal Police Environment Division, discovered that the company was pushing the oil to the bottom of the sea rather than collecting it by placing the corals. in the area at risk of pollution (OLIVEIRA et al., 2017). 


\section{Guanabara Basin 2000}

Another oil spill that became famous in Brazil because of its magnitude was Guanabara Bay occurred in 2000. The problem happened due to a problem occurred in one of the pipes of the Duque de Caxias Refinery (Reduc). This problem led to a leak of about 1.3 million liters of crude oil in Guanabara Bay. A very serious leak that created an oil strip in water over 50 square kilometers. One of the main problems was that the spot reached the mangrove swamp of Guapimirim's environmental protection area (APA). Due to the disaster many species of fauna and flora have been decimated which has led to several losses. In addition to the environmental issue this leak has brought several social and economic losses to the population living in the region. People who lived on activities directly or indirectly linked to Guanabara Bay resources such as fishing and tourism were greatly harmed (MARTINS et al., 2018).

According to Gabriel Elizondo, a Brazilian reporter who published internationally 10 years after the incident (when the site was estimated to recover),

I saw evidence that there is no recovery after all these years. The mud is thick, black and lifeless. And it stinks. Dead stumps - what used to be thick green mangrove - jut out of the mud as far as your eye can see. It looks like a scene captured by a camera attached to an unmanned spaceship that has just landed on a lifeless planet in another galaxy. Nothing is growing here, and I can't imagine anything growing here in a long time. It's sad.

He also reported that local fishermen complained that on an incredible day of fishing, the volume of fish recovered is $10 \mathrm{~kg}$, when before it was at least $100 \mathrm{~kg}$. In a conversation with Herrera, a studious environmentalist on the case, she claimed that

What is happening in many parts of the affected mangrove swamp in Guanabara Bay is the formation of oil bubbles that are below the surface. These bubbles are buried under sediments at the bottom of the bay, and many years later - even decades after the crash we can still see if these bubbles can reappear on the surface. We still get reports from fishermen who report small patches of oil that keep popping up in the mangrove swamp, and that's what it is.

Petrobras has invested more than USS 200 million over the past decade in environmental and social projects in Guanabara Bay and has dramatically improved its environmental track record over the past ten years (it is considered Brazil's most socially responsible company).

\section{Iguacu River Basin (PR) 2000}

This leak is one of the worst ever in Brazil and occurred on July 16, 2000. On that date, in the Bahia do Rio Iguaçu, there was a large leak from the Petrobras refinery in AraucÃiria. More than one million gallons, about four million liters, were released into the environment. Obviously such a disaster has affected the fauna and flora of the region. The worst of the situation is that just a few months before Brazil had already faced another major leak, the Duque de Caxias Refinery in Guanabara Bay, mentioned above.

The Brazilian Institute of Environment (IBAMA) imposed, at that time, fines of 51 million reais to Petrobras and the minister of the environment, José Sarney Filho, warns that, for being repeat and large, the fine to be applied by this new accident will be higher. Petrobrás Environment Superintendent Irani Varela said that collecting oil spilled into rivers is less harmful than at sea because rivers flow in one direction and 
the pollution stain path is therefore predictable. The leak is about three times larger than in Guanabara Bay in January, when it leaked 1.29 million liters (BRITO et al., 2018).

\section{Castelo Branco Highway 2001}

On June 15, 2001 Construtora Galvão was responsible for the LPG (Liquefied Petroleum Gas) leak. The leak occurred in a Petrobras pipeline located at km 20 of the Castelo Branco Highway, one of the most important roads in the state of São Paulo.

The accident happened during the works carried out by the construction company that was hired by the government. The company was fined BRL $98,000.00$ by Cetesb - State Company of Environmental Sanitation Technology of São Paulo. Oil and oil leaks are very serious, as they are toxic substances that are very harmful to the environment. Several species are harmed and people living around these regions are affected as well. Thus it is very important that there is greater care by oil companies.

\section{Transpetro 2012}

In 2012, the amount of oil spilled at sea was 33.6 thousand liters in the Osorio Terminal monobuoy, in Rio Grande do Sul, during a ship unloading operation. The company received two fines for the leak, one from Ibama and one from Fepam. For pollution on the beach, the value is USS 1,190,768 - the oil reached 3.5 thousand meters of shore. For the oil spill in the sea, the amount due to Ibama is USS 1,200. In addition, there is a fine of BRL 500,000 for the use of chemical dispersants - a resolution provides for the use of the product 2,000 meters from the coast and with water at a depth of 15 meters. This is the first time IBAMA has fined the dispersant. In addition, there was a daily fine of BRL 5,000 for non-compliance with the Environmental Monitoring Program until the company's suitability. The Petrobras subsidiary was fined about BRL 2.9 million in total for the oil spill that occurred (SOUZA et al., 2019).

\section{Critical analysis}

Despite the positive contributions made by the oil industry, the negative impact on the physical and social environment produced and accidents such as oil spills and blowouts show the only economic focus of oil exploration and production companies.

\section{Companies Positionings}

Looking at the international environmental disasters it is clear that even though fines and punitive measures are tough, most companies do not have a specific focus on creating environmental remedies and even preventing small or large oil leaks for water bodies or even on land.

One of the biggest international disasters, the spill at the Pesrian Gulf in 1991 at Iraq posed a threat not only to military operations during the war time, but also to the basic continuity of life in the country. The ships managed to recover a total of 35,000 tons of oil and water mixture, offshore and coastal operations recovered a total of 200,000 tonnes of oil and water mix which, when surveys were conducted immediately 
after the spill, and a cost proposal was prepared in which the costs of cleaning up all contaminated margins were estimated at \$540 million. The Iraq invasion and occupation of Kuwait not only caused serious environmental damage, it also produced a human tragedy of death and injury, torture, terror and trauma. Social informations are generally inaccessible, partly because post-war legal settlements are still in progress and partly because of data unavailable due to censorship (LINDÉN et al., 2004).

For weeks, residents of the region were subjected to a series of lively conversations and promises from Washington, Houston, and London made at the media. And the USA government was saying that they would "leave the Gulf Coast in better shape than it once was", that they were "ensuring that" she "would come back even stronger than it was before this crisis", wich didn't happened. Because for people whose livelihoods put them in close contact with the delicate chemistry of wetlands, it seemed ridiculous and painfully, once countless were poisoned. What led to the thinking that for three years, big oil companies spent billions to explore new oil and gas, however, the average investment in research and development for safety, accident prevention and spill response was only $\$ 20$ million per year.

During the spill, desalination plants and industrial facilities were temporarily closed, fishing was disrupted, and large numbers of dead sea animals, so scientists wrote to United Nations Environment Program Director Mostafa Tolba, warning that if the wells burn for a month, they could create a cloud of soot so thick that 'little radiation from the sun will penetrate', and so big that could "cover half the US area," they said the chemicals produced in the fires could trigger acid rai the Gulf region and that oil spills into the sea "will surely destroy marine life". They urged potential leaders to consider the ecological potential damaged throughout catastrophes when making decisions about any military action in the Gulf, once again the reality wasn't that compliant with the needs of those affected.

Another confrontation between media disclosures and reality can be observed in the most recent oil spill that at the right moment is happening in Brazil. At the northeast of the country, a huge spill of ultra heavy oil started in the middle of 2019 and until November had already affected around 225 beaches and many authorities have commented on the issue that several have provoked criticism from impacted communities and environmentalists, so the IBAMA (Brazilian Institute of Environment and Renewable Natural Resources) published on their official website bulletins saying that the Brazilian Navy is investigating the origin from the oil. Many locations were hit and recorded the actual effects on the fauna, such as an observation of turtles killed during the spawning period in more than 8 Brazilian states. That foundation has federal subprojects that organize cleanup groups for the affected areas, mostly volunteers, but still insufficient to contain or disaster, the agency has been publishing teaches notes about how to act and manually clean up all oily waste, and encouraging the population to record every damage and death generated by cataloged people by photos and on their technical bulletins (SEI/IBAMA published in 2019) claim that satellite mapping of the affected areas is difficult, but indicates that the origin of this oil is strange and it is not possible to find a source of leakage in the national territory, thus expressing a great difficulty in categorizing these accidents as it is not prevented (IBAMA, 2019).

Right after the appearance of those spills (ESCOBAR, 2019), sayed that thousands of tons of crude oil 
residue began to wash up on Brazil's northeast seaboard in late August, contaminating hundreds of beaches, estuaries, reefs, and mangroves along a 2500-kilometer stretch of shoreline. And that the first small blobs of oil have arrived at the largest biodiversity hot spot in the southern Atlantic Ocean and that the Brazilian Federal Police believe the spill came from the Bouboulina, a Greek tanker that passed Brazil in late July, wich is consistent with computer simulations based on the distribution of the oil along the coast.

\section{Society in Action}

It is evident that of all the cases cited, the majority did not undergo stringent inspections, or their environmental opinion was not clearly disclosed to the public in the years following the cleanup of the site (which is not fully effective with respect to safety for marine life). Thus, the population would be of great importance in denouncing or requesting greater governmental attention, so that the problem can be definitively resolved.

As mentioned in the section on oil spill clean-up methods, this is an extremely complex process which, despite having many possibilities for solution, to date, there has not even been a case that a single method was fully effective and effective with fast action. It is still possible to verify in additional literature other cleaning technologies that have not yet been implemented, which makes everyone think more about the importance of promoting the creation of new methods of mitigation and containment of oil, such as biodegradable materials that adsorb oil, or supply the in situ burning of hydrocarbons. And the fact that price is a relevant variable in the use of any cleaning method and that even an expensive (preventive) safety process to prevent leaks is less than what will be spent to mitigate the accident later of its occurrence. Thus, there is a more favorable future bias in preventing accidents with new technologies and skilled professionals than working in business mitigation processes.

For Frynas (2012) major oil spills normally take generic responses for changing the behavior of companies with regard to oil spill prevention: mandatory government regulation or voluntary initiatives often pursued under the banner of Corporate Social Responsibility (CSR). The author shows in his paper how the extent voluntary CSR initiatives can be effective in oil spill prevention, in a global is possible to look at the progress among the years around the world in the subject of oil spill prevention, using the companies' 2010 sustainability reports for self-reported oil spill information. His analysis included ten oil companies from OECD countries (including Exxon and Shell, among others) and 10 oil companies from non-OECD countries (including Brazil's Petrobras and Indian Oil, among others) and the results were that oil spill prevention has generally improved over recent decades in outcome of the paper that CSR played.

Another discussion is represented at (HASTINGS, 1999) paper, about the need for a new response to a changing social environment to be followed by field corporations, as a trend in corporate management to consider the social impacts - including the society positioning about some environmental impacts. The author mention the oil industry and the pollution generated as a high risk for the environment that requires extra attention, highlighting a case occurred in 1997 that popular pressure toke a huge multinational out of an exploration area just by conscientizing about the negative impacts generated on the time. Thus, it leads 
to the conclusion that the historical and modern sociopolitical contexts, which include worldwide publicity, stakeholder participation and new legal requirements, have emerged as prominent forces that create a challenging environment in Latin America and all around the world specially on the internet.

Finally, the importance of environmental agencies, nationally and internationally, and their respective notoriety and support of the conscientious population, should be emphasized, as these are organizations that pressure the oil sector to reformulate itself, making less disagreement between the ideal of security and the profitability sought by it.

\section{CONCLUSIONS}

An important manifestation of sustainable development and development practices within the oil and gas industry in industries is needed. This can be through effective environmental management and emergency exit planning in the event of an accident such as those already mentioned. In order to minimize the negative impact of an oil spill, knowledge of the past case is essential as a source of more effective outputs of immediate remediation of the contaminated site.

Knowing that the lack of integrated information about the risk of environmental degradation that can be created by oil exploration and production activities, as well as the environmental response condition for this degradation are the main causes of all permanent environmental damage generated. It is also important that the population be aware of the impacts caused by basing their cultural, economic and social demands on the high degree of devastation of the marine ecosystem and the non reversibility of the damage suffered.

Measures taken anywhere in the world, such as the Double-Hull Law imposed first in the USA, then in Europe in 2002, show how the influence of awareness is international and that the regularization of the oil and gas sector in the environment is a common issue. from various nations. This measure, for example, occurred as a result of the incident with Exxon Valdez and was a significant milestone in the fight to minimize oil spill accidents, with mandatory participation by society in demanding greater safety during the transportation of hydrocarbons.

Therefore, it is concluded that a change in the widely used mitigation methods is vital, as well as the increase of research in this area, since the present work did not have many recent literary sources on the subject, emphasizing during In recent years, despite increasing environmental concerns, oil spill solutions have been poorly studied or publicized.

Interestingly was noticed that the magnitude of an accident of this type is given by the impacts suffered, which have a direct correlation with preventive measures and prevention of previous oil contingency modes, since a large oil spill if quickly cleaned interferes less with the ecosystem that a low leakage rate but which is added daily without effective cleaning.

ACKNOWLEDGEMENTS: This study was financed in part by the the Higher Education Personnel Improvement Coordination (CAPES) - Finance Code 001. Also was financed by by the National Research Council (CNPQ) for 
the aid granted to co-authors. We thank the team and scientists from the Federal University of Pelotas who helped during oil spill research. We thank the coordinators of this project for fostering the search for data on such a field of study and for supporting us in publishing our findings in the Brazilian scientific literature.

\section{REFERENCES}

ARDESHIRI, A.; SWAIT, J.; HEAGNEY, E. C.; KOVAC, M. Willingness-to-pay for coastline protection in New South Wales: Beach preservation management and decision making. Ocean \& Coastal Management, v.178, 2019. DOI: https://doi.org/10.1016/i.ocecoaman.2019.05.007

BAGGA, P. S.; PATWARDHAN, S. D.; SHARMA, S.. A mathematical model for oil spill clean up using ferromagnetic nanoparticles. Offshore Technology Conference, p.37-42, 2018. DOI: http://doi.org/10.4043/28579-MS

BALMER, B.; YLITALO, G.; WATWOOD, S.; QUIGLEY, B.; BOLTON, J.; MULLIN, K.; ROSEL, P.; ROWLES, T.; SPEAKMAN, T.; WILCOX, L.; ZOLMAN, E.; SCHWACKE, L.. Comparison of persistent organic pollutants (POPs) between small cetaceans in coastal and estuarine waters of the northern Gulf of Mexico. Marine Pollution Bulletin, p.239-247, 2019. DOI: https://doi.org/10.1016/j.marpolbul.2019.05.017

BANERJEE, K.; PRAMANIK, P.; MAITY, A.; JOSHI, D. C.; WANI, S. H.; KRISHNAN, P.. Methods of Using Nanomaterials to Plant Systems and Their Delivery to Plants (Mode of Entry, Uptake, Translocation, Accumulation, Biotransformation and Barriers). Advances in Phytonanotechnology, p.123-152 2019. DOI: https://doi.org/10.1016/B978-0-12-815322 2.00005-5

BAUTISTA, N. M.; POTHINI, T.; MENG, K.; BURGGREN, W. W. Behavioral consequences of dietary exposure to crude oil extracts in the Siamese fighting fish (Betta splendens).

Aquatic Toxicology, v.207, p.34-42, 2019. DOI: https://doi.org/10.1016/j.aquatox.2018.11.025

BHARDWAJ, N.; BHASKARWAR, A. N.. A review on sorbent devices for oil-spill control. Environmental Pollution, v.243, p.1758-1771, 2018. DOI:

https://doi.org/10.1016/j.envpol.2018.09.141

BOSCHEN, R. E.; ROWDEN, A. A.; CLARK, M. R.; GARDNER, J. $P$. A.. Mining of deep-sea seafloor massive sulfides: a review of the deposits, their benthic communities, impacts from mining, regulatory frameworks and management strategies. Ocean Coast. Manag., v.84, p.54-67, 2013.

BRITO, I. A.; GARCIA, J. R. E.; SALAROLI, A. B.; FIGUEIRA, R. C. L.; MARTINS, C. C.; CABRAL NETO, A.; GUSSO-CHOUERI, P. K.; CHOUERI, R. B.; ARAUJO, S. B. L.; RIBEIRO, C. A. O.. Embryo toxicity assay in the fish species Rhamdia quelen (Teleostei, Heptaridae) to assess water quality in the Upper Iguaçu basin (Parana, Brazil). Chemosphere, p.207-218, 2018. DOI: https://doi.org/10.1016/j.chemosphere.2018.05.009

BUCELLI, M.; LANDUCCI, G.; HAUGEN, S.; PALTRINIERI, N.; COZZANI, V.. Assessment of safety barriers for the prevention of cascading events in oil and gas offshore installations operating in harsh environment. Ocean Engineering, p.171-185, 2018. DOI:

\section{https://doi.org/10.1016/i.oceaneng.2018.02.046}

CAMUS, L.; SMIT, M. G. D.. Environmental effects of Arctic oil spills and spill response technologies, introduction to a 5 year joint industry effort. Marine Environmental Research, v.144, p.250-254, 2019. DOI:

https://doi.org/10.1016/j.marenvres.2017.12.008

CAO Y.; ZHANG, W.; LI, B.; WANG, P.; FENG, L.; WEI, Y.. Mussel-inspired Ag nanoparticles anchored sponge for oil/water separation and contaminants catalytic reduction. Separation and Purification Technology, v.225, p.18-23, 2019. DOI: https://doi.org/10.1016/i.seppur.2019.05.059

CHEN, B.; YE, X.; ZHANG, B.; JING, L.; LEE, K.. Marine Oil Spills: preparedness and countermeasures. World Seas: an Environmental Evaluation, p.407-426, 2019. DOI: https://doi.org/10.1016/B978-0-12-805052-1.00025-5

CROFTON, J.. Halifax Harbour Integrated Response Plan (HHIRP) for Marine Oil Spills. Dissertation (Master of Marine Management) - Dalhousie University, Halifax, 2019.

DEBS, K. B.; CARDONA, D. S.; SILVA, H. D. T.; NASSAR, N. N.; CARRILHO, E. N. V. M.; HADDAD, P. S.; LABUTO, G.. Oil spill cleanup employing magnetite nanoparticles and yeast-based magnetic bionanocomposite. Journal of Environmental Management, v.230, p.405-412, 2019. DOI: https://doi.org/10.1016/j.jenvman.2018.09.094

DOSHI, B.; SILLANPÄÄ, M.; KALLIOLA, S.. A review of biobased materials for oil spill treatment. Water Research, v.135, p.262-277, 2018. DOI:

https://doi.org/10.1016/j.watres.2018.02.034

DUKE, N. C.. Oil spill impacts on mangroves:

Recommendations for operational planning and action based on a global review. 2016

DUONG, H. M.; LIU, P.; NGUYEN, T. X.; NGUYEN, S. T.; FENG, J.; CHENG, H.. Biobased Aerogels: Polysaccharide and Protein-based Materials. Chapter 14. 2018.

EPA. Environmental Protection Agency. Major Criminal Cases. Clean Air Act. EPA, 2017.

ESCOBAR, H.. Mystery oil spill threatens marine sanctuary in Brazil. Science, v.366, n.6466, p.672, 2019.

EVERS, D. C.; SPERDUTO, M.; GRAY, C. E.; PARUK, J. D.; TAYLOR, K. M.. Restoration of common loons following the North Cape Oil Spill, Rhode Island, USA. Science of The Total Environment, v.695, p.133849, 2019. DOI: https://doi.org/10.1016/j.scitotenv.2019.133849

FAKHRZADEGAN, I.; HASSANSHAHIAN, M.; HESNI, M. A.; SAADATFAR, A.. A study of crude oil-degrading bacteria from mangrove forests in the Persian Gulf. Marine Ecology, v.40, 


\section{n.2, 2019. DOI: https://doi.org/10.1111/maec.12544}

FINGAS, M.. In-Situ Burning for Oil Spill Countermeasures. Taylor \& Francis Group, 2018.

FLACKS, R.. Corporate versus Community Power: A Santa Barbara Story. Journal Of World-Systems Research, v.25, n.1, p.35-41, 2019. DOI: http://doi.org/10.5195/JWSR.2019.904

FOEKEMA, E. M.. Testing the effect of MOSSFA (Marine Oil Snow Sedimentation and Flocculent Accumulation) events in benthic microcosms. In: MURAWSKI, S.; HOLLANDER, D. J.; PARIS, C. B.; SCHLÜTER, M.; GILBERT, S.; AINSWORTH, C. H.; WETZEL, D. L.. Scenarios and responses to future deep oil spills. Springer, 2020. DOI: https://doi.org/10.1007/978-3030-12963-7 17

FOWLER, S. W.. Pollution in the Gulf: Monitoring the marine environment. IAEA Bulletin, 1993.

FRIES, A. S.; COIMBRA, J. P.; NEMAZIE, D. A.; SUMMERS, R. M.; AZEVEDO, J. P. S.; FILOSO, S.; NEWTON, M.; GELLI, G.; OLIVEIRA, R. C. N.; PESSOA, M. A. R.; DENNISON, W. C.. Guanabara Bay ecosystem health report card: Science, management, and governance implications. Regional Studies in Marine Science, v.25, 2019. DOI: https://doi.org/10.1016/j.rsma.2018.100474

FRYNAS, J. G.. Corporate Social Responsibility or Government Regulation? Evidence on Oil Spill Prevention. Ecology and Society, v.17, n.4, 2012.

GAINER, A.; BRESEE, K.; HOGAN, N.; SICILIANO, S. D.. Advancing soil ecological risk assessments for petroleum hydrocarbon contaminated soils in Canada: Persistence, organic carbon normalization and relevance of species assemblages. Science of The Total Environment, v.668, p.400-410, 2019. DOI: https://doi.org/10.1016/j.scitotenv.2019.02.459

GROTE, M.; BERNEM, C. V.; BÖHME, B.; CALLIES, U.; CALVEZ, I.; CHRISTIE, B.; COLCOMB, K.; DAMIAN, H. P.; FARKE, H.; GRÄBSCH, C.; HUNT, A.; HÖFER, T.; KNAACK, J.; KRAUS, U.; FLOCH, S. L.; LANN, G. L.; LEUCHS, H.; NAGEL, A.; NIES, A.; NORDHAUSEN, W.; RAUTERBERG, J.; REICHENBACH, D.; SCHEIFFARTH, G.; SCHWICHTENBERG, F.; THEOBALD, N.; VOß, V.; WAHRENDORF, D. S.. The potential for dispersant use as a maritime oil spill response measure in German Waters. Marine Pollution Bulletin, p.623-632, 2018. DOI: https://doi.org/10.1016/j.marpolbul.2017.10.050

GUO, W.; ZHANG, S.; WU, G.. Quantitative oil spill risk from offshore fields in the Bohai Sea. Science of The Total Environment, v.688, p.494-504, 2019. DOI: https://doi.org/10.1016/j.scitotenv.2019.06.226

HADER, D. P.. Pollution Dynamics of Organic Contaminants $\mathrm{i}$ Marive Ecosystems. Marine Ecology, v.1, p.91-113, 2019.

HAO, J.; MOHAMMADKHANI, S.; SHAHVERDI, H.; ESFAHANY, M. N.; SHAPIRO, A.. Mechanisms of smart waterflooding in carbonate oil reservoirs: A review. Journal of Petroleum Science and Engineering, v.179, p.276-291, 2019. DOI: https://doi.org/10.1016/i.petrol.2019.04.049

HASTINGS, M.. A new operational paradigm for oil operations in sensitive environments: an analysis of social pressure, corporate capabilitie sand competitive advantage. Business Strategy and the Environment, p.267-280, 1999.

HAZRA, B.; WOOD, D. A.; MANI, D.; SINGH, P. K.; SINGH A. K.. Sedimentary Biomarkers and Their Stable Isotope Proxies in Evaluation of Shale Source and Reservoir Rocks. In: EVALUATION OF SHALE SOURCE ROCKS AND RESERVOIRS PETROLEUM ENGINEERING. Annals. Springer, 2019. DOI: https://doi.org/10.1007/978-3-030-13042-8 6

HOANG A. T.; PHAM, X. D.. An investigation of remediation and recovery of oil spill and toxic heavy metal from maritime pollution by a new absorbent material. Journal of Marine Engineering \& Technology, p.1-11, 2018. DOI: https://doi.org/10.1080/20464177.2018.1544401

HOANG, A. T.; PHAM, V. V.; NGUYEN, D. N.. A report of oil spill recovery technologies. International Journal of Applied Engineering Research, v.13, p.4915-4928, 2018.

HOANG, P. H.; HOANG, A. T.; CHUNG, N. H.; DIEN, L. Q.; NGUYEN, X. P.; PHAM, X. D.. The efficient lignocellulosebased sorbent for oil spill treatment from polyurethane and agricultural residue of Vietnam. Energy Sources, Part A: Recovery, Utilization, and Environmental Effects, v.40, n.3, p.312-319, 2018. DOI: http://doi.org/10.1080/15567036.2017.1415397

HSU, C. S.; ROBINSON, P. R.. Petroleum System and Occurrence. Petroleum Science and Technology, Springer, 2019. DOI: https://doi.org/10.1007/978-3-030-16275-7 5

HSU, C. S.; ROBINSON, P. R.. Safety and Environment. Petroleum Science and Technology, Springer, 2019. DOI: https://doi.org/10.1007/978-3-030-16275-7 18

ICLG. International Comparative Legal Guides. Environment \& Climate Change Law 2019. 16 ed. ICLG, 2019.

IFELEBUEGU, A. O.; JOHNSON, A.. Nonconventional low-cost cellulose- and keratin-based biopolymeric sorbents for oil/water separation and spill cleanup: A review. Environmental Science and Technology, p.964-1001, 2017. DOI: http://doi.org/10.1080/10643389.2017.1318620

JI, Q.; ZHANG, H. Y.; ZHANG, D.. The impact of OPEC on East Asian oil import security: A multidimensional analysis.

Energy Policy, v.126, p.99-107, 2019. DOI:

https://doi.org/10.1016/i.enpol.2018.11.019

JIMÉNEZ, S.; MICÓ, M. M.; ARNALDOS, M.; MEDINA, F.; Contreras, S.. State of the art of produced water treatment. Chemosphere, v.192, p.186-208, 2018. DOI: https://doi.org/10.1016/j.chemosphere.2017.10.139

JØRGENSEN, K. S.; KREUTZER, A.; LEHTONEN, K. K.; KANKAANPÄÄ, H.; RYTKÖNEN, J.; WEGEBERG, S.; GUSTAVSON, K.; FRITT-RASMUSSEN, J.; TRUU, J.; KÕUTS, T.; LILOVER, M.-J.; SEILER, T.-B.; HOLLERT, H.; JOHANN, S.; MARIGÓMEZ, I.; SOTO, M.; LEKUBE, X.; JENSSEN, B. M.; CIESIELSKI, T. M.; WILMS, L. B.; HÖGSTRÖM, R.; PIRNESKOSKI, M.; VIRTANEN, S.; FORSMAN, B.; PETRICH, C.; PHUONG-DANG, N.; WANG, F.. The EU Horizon 2020 project GRACE: integrated oil spill response actions and environmental effects. Environ Sci Eur, v.31, n.44, 2019. DOI: https://doi.org/10.1186/s12302-019-0227-8 
KALU, K.; OTT, K.. Ethical issues in environmental pollution: Multinational Corporations (MNCs) and Oil Industries in Tropical Regions: The Nigerian Niger-Delta Case. Chemhuru M. African Environmental Ethics. The International Library of Environmental, Agricultural and Food Ethics, Springer, v.2, 2019. DOI: https://doi.org/10.1007/978-3-030-18807$\underline{818}$

KASPERSON, R. E.; KASPERSON, J. X.; HOHENEMSER, C.; KATES, W. R.; SVENSON, O.. Corporate management of health and safety hazards: a comparison of current practice. Taylor and Francis, 1988.

KLETZ, T.; AMYOTTE, P.. What Went Wrong? Cases histories of procss plant disasters and how they could have been avoided. Butterworth-Heinemann, 2019.

KOULOUKOUI, D.; MARINHO, M. M. O.; GOMES, S. M. S.; KIPERSTOK, A.; TORRES, E. A.. Corporate climate risk management and the implementation of climate projects by the world's largest emitters. Journal of Cleaner Production, v.238, 2019. DOI:

https://doi.org/10.1016/i.jclepro.2019.117935

KUMARI, A.; KAUR, R.; KAUR, R.. A review on fate and remediation techniques of oil spills. International Journal of Research in Pharmeceutical Sciences, v.1, p.111-116, 2018. DOI: https://doi.org/10.26452/ijrps.v10i1.1786

LANGTON, R.; AUGYTE, S.; PRICE, N.; FORSTER, J.; NOJI, T.; GREBE, G.; GELAIS, A. S.; BYRON C. J.. An ecosystem approach to the culture of seaweed. U.S. Department of Commerce National Oceanic and Atmospheric Administration, 2019.

LASSALLE, G.; CREDOZ, A.; HÉDACQ, R.; BERTONI, G.; DUBUCQ, D.; FABRE, S.; ELGER, A.. Estimating persistent oil contamination in tropical region using vegetation indices and random forest regression. Ecotoxicology and Environmental Safety, v.184, p.2-8, 2019. DOI: https://doi.org/10.1016/i.ecoenv.2019.109654

LATIF, S. A.; ISKANDAR, T. A. Y. T.. Antecedents of waste management in the oil and gas industry. EnvironmentBehaviour Proceedings Journal, v.4, n.10, p.136-139, 2019. DOI: https://doi.org/10.21834/e-bpj.v4i10.1634

LEE, C.; HONG, S.; NOH, J.; LEE, J.; YOON, S. J.; KIM, T.; KIM, H.; KWON, B.; LEE, H.; HA, S. Y.; RYU, J.; KIM, J.; KWON, K. K.; YIM, U. K.; KHIM, J. S.. Comparative evaluation of bioremediation techniques on oil contaminated sediments in long-term recovery of benthic community health. Environmental Pollution, v.252, 2019. DOI: https://doi.org/10.1016/j.envpol.2019.05.100

LINDÉN, A. J. O.; JERNELOEV, A.; EGERUP, J.. The Environmental Impacts of the Gulf War 1991. Laxenburg: International Institute for Applied Systems Analysis, 2004.

LI, S.; GRIFOLL, M.; ESTRADA, M.; ZHENG, P.; FENG, H.. Optimization on Emergency Materials Dispatching Considering the Characteristics of Integrated Emergency Response for Large-Scale Marine Oil Spills. Regulatory Framework and Integrated Marine Management, v.7, n.7, 2019. DOI: https://doi.org/10.3390/jmse7070214
LIU, B.; LI, Y.; LI, G.; LIU, A.. A spectral feature based convolutional neural network for classification of sea surface oil spill. ISPRS Int. J. Geo-Inf., v.8, n.4, p.16, 2019. DOI: https://doi.org/10.3390/ijgi8040160

LIU, F.; TU, T.; LI, S.; CAI, M.; HUANG, X.; ZHENG, F.. Relationship between plankton-based $\beta$-carotene and biodegradable adaptablity to petroleum-derived hydrocarbon. Chemosphere, v.237, 2019. DOI: https://doi.org/10.1016/i.chemosphere.2019.124430

LIU, J.; WANG X.. A new method to prepare oil adsorbent utilizing waste paper and its application for oil spill cleanups. BioResources, p.3886-3898, 2019.

MARTINS, M. V. A.; RODRIGUES, R.; PEREIRA, E.; MIRANDA, P.; LAUT, L.; BELART, P.; VILLENA, H. H.; GERALDES, M. C.; SOUSA, S. H. M.; DULEBA, W.; BERGAMASHI, D.. Organic pollution in the ne sector of guanabara bay. Journal of Sedimentary Enviroments, v.3, n.3, 2018. DOI: https://doi.org/10.12957/jse.2018.37826

MITCHELMORE, C. L.; GRIFFITT, R. J.; COELHO, G. M.; WETZEL, D. L.. Modernizing protocols for aquatic toxicity testing of oil and dispersant. Scenarios and Responses to Future Deep Oil Spills, Springer, p.239-252, 2020. DOI: https://doi.org/10.1007/978-3-030-12963-7 14

MULLIN, J. V.. Continuing to improve oil spill response in the arctic: a joint industry programme. In: HILDEBRAND L.; BRIGHAM L.; JOHANSSON T.. Sustainable shipping in a changing arctic. WMU Studies in Maritime Affairs. 7 ed. Springer, 2018. DOI: https://doi.org/10.1007/978-3-31978425-0 19

MURALIKRISHNA, I. V.; MANICKAM, V.. Environmental management science and engineering for industry. Elsevier, 2017.

MURAWSKI, S. A.; AINSWORTH, C. H.; GILBERT, S.; HOLLANDER, D. J.; PARIS, C. B.; SCHLÜTER, M.; WETZEL, D. L.. Deep Oil Spills. Springer, 2020.

NAIR, S.; ABRAHAM, J.. Hazardous Waste Management with Special Reference to Biological Treatment. Handbook of Environmental Materials Management, Springer, p.715740, 2019. DOI: https://doi.org/10.1007/978-3-319-7364571121

NELSON, R. K.; GOSSELIN, K. M.; HOLLANDER, D. J.; MURAWSKI, S. A.; GRACIA, A.; REDDY, C. M.; RADOVIĆ, J. R. Exploring the complexity of two iconic crude oil spills in the gulf of Mexico (Ixtoc I and Deepwater Horizon) Using comprehensive two-dimensional gas chromatography (GC $\times$ GC). Energy \& Fuels, v.33, n.5, p.3925-3933, 2019. DOI: http://doi.org/10.1021/acs.energyfuels.8b04384

NISSANKA, I.; YAPA, P.. Oil droplet size model for ocean surface oil spills: impact of breaking wave height and oil properties. In: MORATUWA ENGINEERING RESEARCH CONFERENCE. Annals. IEEE, 2019. p.303-307. DOI: http://doi.org/10.1109/MERCon.2019.8818912

ODUKOYA, J.; LAMBERT, R.; SAKRABANI, R.. Understanding the impacts of crude oil and its induced abiotic stresses on agrifood production: a review. Horticulturae, v.5, n.2, p.127, 2019. DOI: 
https://doi.org/10.3390/horticulturae5020047

OLARANONT, Y.; STEWART, A. B.; TRAIPERM, P. Physiological and anatomical responses of a common beach grass to crude oil pollution. Environmental Science and Pollution Research, v.25, p.28075-28085, 2018 DOI: https://doi.org/10.1007/s11356-018-2808-2

OLIVEIRA, B. L. A.; NETTO, T. A.; ASSAD, L. P. F.. Threedimensional oil dispersion model in the Campos Basin, Brazil. Environmental Technology, v.39, n.3, 2017. DOI: https://doi.org/10.1080/09593330.2017.1298678

OSTROM, L. T.; WILHELMSEN, C. A.. Risk assessment: tools, techniques, and their applications. John Wiley \& Sons, 2019.

OVERTON, E. B.; WETZEL, D. L.; WICKLIFFE, J. K.; ADHIKARI, P. L.. Spilled Oil Composition and the Natural Carbon Cycle: The True Drivers of Environmental Fate and Effects of Oil Spills. In: MURAWSKI, S.; HOLLANDER, D. J.; PARIS, C. B.; SCHLÜTER, M.; GILBERT, S.; AINSWORTH, C. H.; WETZEL, D. L.. Scenarios and responses to future deep oil spills. Springer, 2020. DOI: https://doi.org/10.1007/978-3-030$\underline{12963-7 \quad 3}$

PENG, Y.; WEN, G.; GOU, X.; GUO, Z.. Bioinspired fish-scalelike stainless steel surfaces with robust underwater anticrude-oil-fouling and self-cleaning properties. Separation and Purification Technology, v.202, p.111-118, 2018. DOI: https://doi.org/10.1016/i.seppur.2018.03.035

PIKOVSKIY, Y. I.; ISMAILOV, N. M.; DOROKHOVA, M. F.. Oil and gas environmental ecology. Academus Publishing, 2019.

ROLANDSEN, M. H.. Oil spill preparedness and response in the arctic. The Arctic University of Norway, 2018.

ROS, Z. D.; DELL'ANNO, A.; MORATO, T.; SWEETMAN, A. K.; SILVA, M. C.; SMITH, C. J.; PAPADOPOULOU, N.; CORINALDESI, C.; BIANCHELLI, S.; GAMBI, C.; CIMINO, R.; SNELGROVE, P.; LEE C.; DOVER, V.; DANOVARO, R.. The deep sea: The new frontier for ecological restoration. Marine Policy, v.108, p.1-7, 2019. DOI:

https://doi.org/10.1016/j.marpol.2019.103642

RYPKEMA, H. A.. Chapter 2.1: Environmental chemistry, renewable energy, and global policy. Green Chemistry, p.19-47, 2018. DOI: https://doi.org/10.1016/B978-0-12809270-5.00002-9

SAMUDRE, R.; KHATRI, S.; SAKPAL, N.; PATWARDHAN, S. Modelling of critical parameters of oil spill. Society of Petroleum Engineers, 2019. DOI:

http://doi.org/10.2118/194612-MS

SCHWING, P. T.; MACHAIN-CASTILLO, M. L.. Impact and Resilience of Benthic Foraminifera in the Aftermath of the Deepwater Horizon and Ixtoc 1 Oil Spills. In: MURAWSKI, S. A.; AINSWORTH, C. H.; GILBERT, S.; HOLLANDER, D. J.; PARIS, C. B.; SCHLÜTER, M.; WETZEL, D. L.. Deep Oil Spills. Springer, 2020. DOI: https://doi.org/10.1007/978-3-030-11605-7 23

SERPA, N.; CATHCART, R. B.. Guanabara Bay: Proposals for a Territory of Exclusion Born from Paradise: Part I, The Present-Day Mess. Calibre, v.4, n.1, p.1-11, 2019. DOI: http://dx.doi.org/10.17648/calibre.v4i1.598
SHAH, M. U. H.; MONIRUZZAMAN, M.; SIVAPRAGASAM, M.; TALUKDER, M. M. R.; YUSUP, S. B.; GOTO, M.. A binary mixture of a biosurfactant and an ionic liquid surfactant as a green dispersant for oil spill remediation. Journal of Molecular Liquids, v.280, p.111-119, 2019 DOI: https://doi.org/10.1016/j.molliq.2019.02.049

SHANG, Z.; ZHENG, X.; MA, Y.. Characteristic model of soil pollution in petroleum exploration area based on multivariate analysis. Ekoloji Dergisi, v.28, n.107, p.38173826, 2019.

SILVA, D. P.; DUARTE, G.; VILLELA, H. D. M.; SANTOS, H. F.; ROSADO, P. M.; ROSADO, J. G.; ROSADO, A. S.; FERREIRA, E. M.; SORIANO, A. U.; PEIXOTO, R. S.. Adaptable mesocosm facility to study oil spill impacts on corals. Ecology and Evaluation, v.9, n.9, p.5172-5185, 2019. DOI: https://doi.org/10.1002/ece3.5095

SIMONSEN, G.; STRAND, M.; ØYE, G.. Potential applications of magnetic nanoparticles within separation in the petroleum industry. Journal of Petroleum Science and Engineering, v.165, p.488-495, 2018. DOI: https://doi.org/10.1016/i.petrol.2018.02.048

SØRENSEN, L.; HANSEN, B. H.; FARKAS, J.; DONALD, C.; ROBSON, W.; TONKIN, A.; MEIER, S.; ROWLAND, S. J. Accumulation and toxicity of monoaromatic petroleum hydrocarbons in early life stages of cod and haddock. Environmental Pollution, v.251, p.212-220, 2019. DOI: http://doi.org/10.1016/j.envpol.2019.04.126

SØRHEIM, K. R.; BAKKEN, O. M.; PETTERSEN, T. A.; LEIRVIK, F.. Brasse crude oil: Properties and behaviour at sea. SINTEF Ocean, 2018

SOUZA, S. S.; OLEINIK, P. H.; MONTEIRO, C. B.; MARQUES, W. C.. Modelagem e simulação de derrames de dois tipos de petróleo baseado na experiência de Tramandaí/RS. RIPE, v.5, n.1, 2019. DOI: http://doi.org/10.26512/ripe.v5i1.19242

SPEIGHT, J. G.; RADOVANOVIĆ, L.. Natural gas: an energy and environmental savior during the 21st century. In: ACTA TECHNICA CORVINIENSIS - BULLETIN OF ENGINEERING; 12. Annals. Hunedoara, 2019. p.121-124.

SPEZIO, T. S.. The Santa Barbara Oil Spill and Its Effect on United States Environmental Policy. Environmental Analysis Program, Pitzer College, Claremont, v.10, n.8, 2018. DOI: https://doi.org/10.3390/su10082750

SUÁREZ, A.; ILIZÁSTIGUI, F.. Risk management of major oil spill. Society of Petroleum Engineers, p.1-14, 2018. DOI: http://doi.org/10.2118/191183-MS

SUN, S.; ZHU, L.; LIU, X.; WU, L.; DAI, K.; LIU, C.; SHEN, C.; GUO, X.; ZHENG, G.; GUO, G.. Superhydrophobic Shish-kebab Membrane with Self-Cleaning and Oil/Water Separation Properties. American Chemical Society, v.6, n.8, p.98669875, 2018. DOI: https://doi.org/10.1021/acssuschemeng.8b01047

TAYLOR, S. E.; CHU, H. T.. Metal Ion Interactions with Crude Oil Components: Specificity of $\mathrm{Ca} 2+$ Binding to Naphthenic Acid at an Oil/Water Interface. Colloids and Interfaces in Oil Recovery, p.2-21, 2018. DOI: https://doi.org/10.3390/colloids2030040 
TOZ, A. C.; KOSEOGLU, B.. Trajectory prediction of oil spill with Pisces 2 around Bay of Izmir, Turkey. Marine Pollution Bulletin, v.126, p.215-227, 2018. DOI:

https://doi.org/10.1016/j.marpolbul.2017.08.062

VARJANI, S.; UPASANI, V. N.. Influence of abiotic factors, natural attenuation, bioaugmentation and nutrient supplementation on bioremediation of petroleum crude contaminated agricultural soil. Journal of Environmental Management, v.245, p.358-366, 2019. DOI:

https://doi.org/10.1016/i.jenvman.2019.05.070

VARSAMI, C.; TROMIADIS, R.. An analysis of maritime accidents involving oil tankers from a structural point of view. Scientific Bulletin Naval Academy, Constanta, v.21, n.1, p.1-8, 2018. DOI: http://doi.org/10.21279/1454-864X$\underline{18-\mid 1-010}$

VASSILIOU, M. S.. Historical dictionary of the petroleum industry. 2 ed. Rowman \& Littlefield, 2018.

VIDMAR, P.; PERKOVIČ, M.. Safety assessment of crude oil tankers. Safety Science, v.105, p.178-191, 2018. DOI: https://doi.org/10.1016/j.ssci.2018.02.009

WADHWANI, R.. Oil spill cleanup using aerographene. Society of Petroleum Engineers, p.1-9, 2017. DOI: http://doi.org/10.2118/185401-MS1-9

WALKER, A. H.; SCHOLZ, D.; MCPEEK, M.; FRENCH-MCCAY, D.; ROWE, J.; BOCK, M.; ROBINSON, H.; WENNING, R.
Comparative risk assessment of spill response options for a deepwater oil well blowout: Part III. Stakeholder engagement. Marine Pollution Bulletin, v.133, p.970-983.

WILKINSON, J.; BEEGLE-KRAUSE, EVERS, K. U.; HUGHES, N.; LEWIS, A.; REED, M.; WADHAMS, P.. Oil spill response capabilities and technologies for ice-covered Arctic marine waters: A review of recent developments and established practices. Ambio, v.46, p.423-441, 2017. DOI: http://doi.org/10.1007/s13280-017-0958-y

ZAFIRAKOU A.; THEMELI, S.; TSAMI E.; ARETOULIS, G.. MultiCriteria Analysis of Different Approaches to Protect the Marine and Coastal Environment from Oil Spills. Journal od Marine Science and Engineering, v.6, n.4, p.125, 2018. DOI: https://doi.org/10.3390/jmse6040125

ZHANG, B.; MATCHINSKI, E. J.; CHEN, B.; YE, X.; JING, L.; LEE, K.. Chapter 21: Marine Oil Spills: Oil Pollution, Sources and Effects. World Seas: an Environmental Evaluation, p.391406, 2019. DOI: https://doi.org/10.1016/B978-0-12-8050521.00024-3

ZHU, Z.; ZHAO, C.; YI, J.; LIU, N.; CAO, Y.; DECKER, E. A.; MCCLEMENTS, D. J.. Impact of Interfacial Composition on Lipid and Protein Co-Oxidation in Oil-in-Water Emulsions Containing Mixed Emulisifers. J. Agric. Food Chem., v.66, n.17, p.4458-4468, 2018. DOI: https://doi.org/10.1021/acs.jafc.8b00590

ZOVEIDAVIANPOOR, M.. Recent insights in petroleum science and engineering. 2018.

A CBPC - Companhia Brasileira de Produção Científica (CNPJ: 11.221.422/0001-03) detém os direitos materiais desta publicação. Os direitos referem-se à publicação do trabalho em qualquer parte do mundo, incluindo os direitos às renovações, expansões e disseminações da contribuição, bem como outros direitos subsidiários. Todos os trabalhos publicados eletronicamente poderão posteriormente ser publicados em coletâneas impressas sob coordenação da Sustenere Publishing, da Companhia Brasileira de Produção Científica e seus parceiros autorizados. Os (as) autores (as) preservam os direitos autorais, mas não têm permissão para a publicação da contribuição em outro meio, impresso ou digital, em português ou em tradução. 